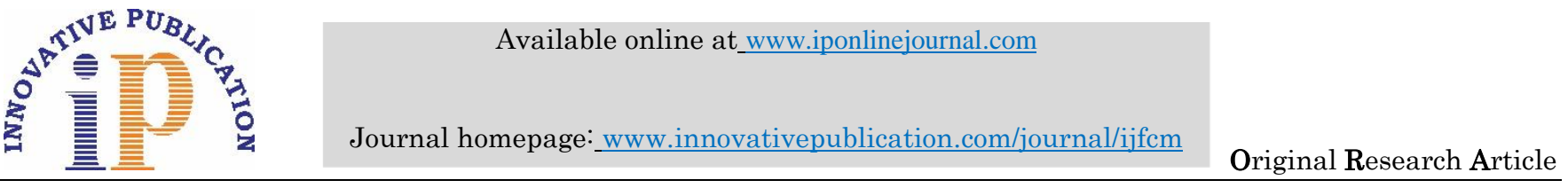

\title{
A cross-sectional study on domestic violence among married women of reproductive age in rural mandya
}

\author{
J Vinay $^{1}$, S K Raghavendra ${ }^{2 *}$, P Thejaswini ${ }^{3}$, AG Vijay Kumar ${ }^{4}$ \\ ${ }^{1,2}$ Assistant Professor, ${ }^{3}$ Medical Officer, ${ }^{1,4}$ Dept. of Forensic Medicine and Toxicology, ${ }^{3}$ Dept. of Community Medicine, \\ ${ }_{\mathbf{1 , 2}, \mathbf{4}}$ Adichunchanagiri Institute of Medical sciences, B G Nagar, Mandya, Karnataka, ${ }^{3}$ Primary Health Centre, Gov of Karnataka, India
}

\begin{abstract}
Introduction: Domestic violence against women is a global problem and present in every country cutting across the boundaries of culture, class, education, income, ethnicity and age. It has serious consequences on the women's mental, physical, reproductive and sexual health. Materials and Methods: A community based, cross-sectional study was conducted from 200 women of reproductive age (18-49 years) residing in rural field practice area of Adichunchanagiri Institute of Medical Sciences (AIMS), Mandya, Karnataka, with a predesigned, pretested, semi-structured questionnaire, pertaining to the socio-demographic parameters, type, frequency, modes, reasons for domestic violence and legal support seeking behaviour in them. Data was analysed using descriptive and inferential statistics.

Results: The prevalence of domestic violence was found to be $39.5 \%$. The common type of domestic violence was psychological violence $59(74.7 \%)$, followed by $35(44.3 \%)$ had physical violence and $15(18.9 \%)$ sexual violence. Insult (84.7\%), beating and slapping and pressure for sex $12(80 \%)$, were the most common types of violence's observed respectively. Husband was the $48(60.8 \%)$ most common perpetrator of domestic violence. Alcohol addiction of husband was the leading cause for domestic violence. The common reason to stay in violent relationship was for children $55(69.6 \%)$, the common response to violence was tolerating $57(72.2 \%)$. Domestic violence significantly associated with factors such as occupational status of the women includes agriculture, business \& government service, husband's educational status such as graduation \& primary school education and with their habits of smoking \& alcohol consumption. The legal help seeking behaviour was very less $7(8.9 \%)$ and most common reason cited was social stigma $22(27.8 \%) \%)$.

Conclusion: About one third of the women in the reproductive age group were exposing to domestic violence and psychological violence was the most common type. The occupational status of the women, such as agriculture, business \& government service, the husband's, educational status including graduation \& primary school education, and alcohol \& smoking habits were independent risk factors for developing domestic violence. The legal help seeking behaviour of the women was very low.
\end{abstract}

Keywords: Domestic violence, Reproductive age, Women, Rural.

\section{Introduction}

The World Health Organization defines domestic violence as "the range of physically, psychologically and sexually coercive acts used against adult and adolescent women by current or former male intimate partners." It is a global issue, deeply ingrained across national boundaries in all racial, cultural and socio-economic classes. It is estimated that about $20 \%-50 \%$ of women in most countries have experienced domestic violence from an intimate partner. ${ }^{2}$ Domestic violence has widespread societal problem with consequences reaching far beyond the family. There is growing evidence that violence within the family becomes the breeding ground for other social problems such as substance abuse, juvenile delinquency, and violent crimes of all types. Even though it is perpetrated by men and women, most commonly, the victims are women and the perpetrators are their husbands, followed by in-laws.

Domestic violence also goes by many names: wife abuse, marital assault, woman battery, spouse abuse, wife beating, conjugal violence, intimate violence, battering, partner abuse, and so forth. As per the World Bank report, one work day out of each five lost by women is because of health problems emerging out of domestic violence. Domestic violence as such not only causes physical harm, which undermines the social, psychological, financial, and emotional well-being of not only the victim, but of the society as a whole. It has serious consequences on the women's mental, physical, reproductive and sexual health leading to temporary or permanent disabilities, depression and suicide amongst others. According to National Family Health Survey (NFHS) - IV in India, among women aged $15-49$ years, $31.1 \%$ of women experienced spousal violence after marriage, amongst 34\% were reported from rural families itself. In relation to type, $23 \%$ have ever experienced physical violence, and $9 \%$ have ever experienced sexual violence. Of which, only $22 \%$ of women who have ever experienced physical or sexual violence by anyone have sought help. But only $4 \%$ of abused women who sought help for the violence from the police. ${ }^{3}$

In Indian scenario, there is a dearth of information on this issue, specifically on prevalence of domestic violence and its associated factors in rural area. Thus, the present study was conducted in field practice area of AIMS, Mandya, on rural population of married women of

\footnotetext{
*Corresponding Author: S K Raghavendra, Dept. of Forensic Medicine and Toxicology, ${ }^{4}$ Adichunchanagiri Institute of Medical sciences, B G Nagar, Mandya, Karnataka, India

Email: nanragakhu@gmail.com

http://doi.org/10.18231/J.JJFCM.2019.042
} 
reproductive age 18-49 years to study the prevalence, type of violence, factors associated with it and legal support seeking behaviour of these women, so that it provides suggestions to the lawmakers and enables judiciary system to handle medico-legal issues in the appropriate manner.

\section{Objectives}

1. To determine the prevalence of domestic violence among married women of reproductive age 18-49 years.

2. To determine the pattern of domestic violence among these women.

3. To assess factors influencing domestic violence

4. To assess the legal support seeking behaviour of these women.

\section{Materials and Methods}

A community based, descriptive cross-sectional study was conducted in rural field practice area of AIMS, Mandya, India for a period of 3 months from $1^{\text {st }}$ December 2018 to $28^{\text {th }}$ February 2019 using convenient sampling method with sample size of 200. The study sample includes all married women in the reproductive age of 18-49 years living with their spouses and/or his family members at least for past 12 months. Using a predesigned, pretested, semi-structured questionnaire, which is translated to local language
Kannada, data was collected. Informed written consent was taken from each of the participants after confidentiality of their responses was assured and the purpose of study was explained. The questionnaire includes information pertaining to the socio-demographic parameters, type, frequency, modes, reasons for domestic violence and legal support seeking behaviour among them.

\section{Inclusion criteria}

Married women in the age group between 18-49 years who were willing to participate in the study.

\section{Exclusion criteria}

Participants who were seriously ill and not present during the time of the study.

\section{Statistical analysis}

The data was entered into MS Excel 2016 and analysed using IBM SPSS 20 statistics package. Data was expressed in terms of means and proportions. To test the significance of categorical variables, multiple logistic regression was done. A p value $\leq 0.05$ was considered as statistically significant.

\section{Results}

Table 1: Socio-demographic profiles of the study subjects

\begin{tabular}{|c|c|c|c|}
\hline Variables & Category & Frequency & Percentage \\
\hline \multirow{4}{*}{ Age group } & $18-27$ & 66 & 33.0 \\
\hline & $28-37$ & 87 & 76.5 \\
\hline & $\geq 38$ & 47 & 23.5 \\
\hline & Total & 200 & 100.0 \\
\hline \multirow[t]{4}{*}{ Age at marriage } & $15-17$ years & 40 & 20 \\
\hline & $18-21$ & 117 & 58.5 \\
\hline & $22-25$ & 43 & 21.5 \\
\hline & Total & 200 & 100.0 \\
\hline \multirow[t]{4}{*}{ Duration of married life } & $\leq 7$ years & 68 & 34.0 \\
\hline & $8-15$ years & 73 & 36.5 \\
\hline & $\geq 16$ years & 59 & 29.5 \\
\hline & Total & 200 & 100.0 \\
\hline \multirow[t]{4}{*}{ Religion } & Hindu & 173 & 86.5 \\
\hline & Muslim & 25 & 12.5 \\
\hline & Christian & 2 & 1.0 \\
\hline & Total & 200 & 100.0 \\
\hline \multirow{6}{*}{$\begin{array}{l}\text { Socio-economic status } \\
\text { (modified BG Prasad } \\
\text { classification) }\end{array}$} & Upper & 6 & 3.0 \\
\hline & Upper middle & 35 & 17.5 \\
\hline & Middle & 92 & 46.0 \\
\hline & Lower middle & 44 & 22.0 \\
\hline & Lower & 23 & 11.5 \\
\hline & Total & 200 & 100.0 \\
\hline
\end{tabular}

In the present study, data was collected from 200 married women of reproductive age (18-49 years) from rural field practice area of AIMS, Mandya, India. The majority of women were in the age group of 28-37 years (76.5\%) with the mean age (31.5 \pm 6.9$)$ years \& range of $19-49$ years. $58.5 \%$ of the individuals were married at the age $18-21$ years. The duration of married life among $34 \%$ of individual was less than 7 years and $36.5 \%$ of individuals were between $8-15$ years and remaining $29.5 \%$ were $\geq 16$ years. With respect to religion, $173(86.5 \%)$ were Hindus and 25(12.5\%) were Muslims. Regarding socio 
economic status, (as per modified BG Prasad classification) 46.0\% belonged to middle class, $22.0 \%$ were lower middle class, and $17.5 \%$ were in the upper middle class.

Table 2: Socio-demographic profiles of the study subjects in relation to education and occupation.

\begin{tabular}{|c|c|c|c|c|c|}
\hline \multirow[t]{2}{*}{ Variables } & \multirow[t]{2}{*}{ Category } & \multicolumn{2}{|c|}{ Married women } & \multicolumn{2}{|c|}{ Husband } \\
\hline & & Frequency & Percentage & Frequency & Percentage \\
\hline \multirow{6}{*}{$\begin{array}{l}\text { Educational } \\
\text { status }\end{array}$} & Illiterate & 47 & 22.5 & 9 & 4.5 \\
\hline & Primary & 51 & 25.5 & 27 & 13.5 \\
\hline & Secondary & 43 & 21.5 & 104 & 52.0 \\
\hline & Pre-university & 52 & 26 & 33 & 16.5 \\
\hline & Graduate & 7 & 3.5 & 27 & 13.5 \\
\hline & Total & 200 & 100 & 200 & 100 \\
\hline \multirow{9}{*}{$\begin{array}{l}\text { Occupation } \\
\text { status }\end{array}$} & Professional & 3 & 1.5 & 2 & 1.0 \\
\hline & Government service & 22 & 11.0 & 1 & 0.5 \\
\hline & Private sector & 3 & 1.5 & 10 & 5 \\
\hline & Business & 0 & 0.0 & 14 & 7 \\
\hline & Agriculture & 25 & 12.5 & 28 & 14 \\
\hline & Labour & 9 & 4.5 & 77 & 38.5 \\
\hline & Housewife & 129 & 64.5 & 52 & 26.0 \\
\hline & Other & 9 & 4.5 & 16 & 8 \\
\hline & Total & 200 & 100 & 200 & 100 \\
\hline
\end{tabular}

Regarding education of women (Table 2), $22.5 \%$ were illiterate, $25.5 \%$ were educated up to primary school, $21.5 \%$ were studied up to secondary school, $26 \%$ studied till pre-university and remaining $3.5 \%$ study population were graduates. In relation to occupation, $64.5 \%$ of them were housewives $12.5 \%$ were agriculturists and $11.0 \%$ had government job.

As far as education of husband was concerned, $52 \%$ of them have been studied up to secondary school, $16.5 \%$ were studied up topre-university, $13.5 \%$ each were graduates and primary school education respectively. By occupation, $38.5 \%$ of them were dependent on agriculture, $26 \%$ were labourers and $14.0 \%$ were businessmen.

In relation to habits of husband as stated by their wives, $72(36.0 \%)$ were smokers, $71(35.5 \%)$ were alcohol users, $5(2.5 \%)$ had habit of gambling and $3(1.5 \%)$ were believed to be having illegal affair.

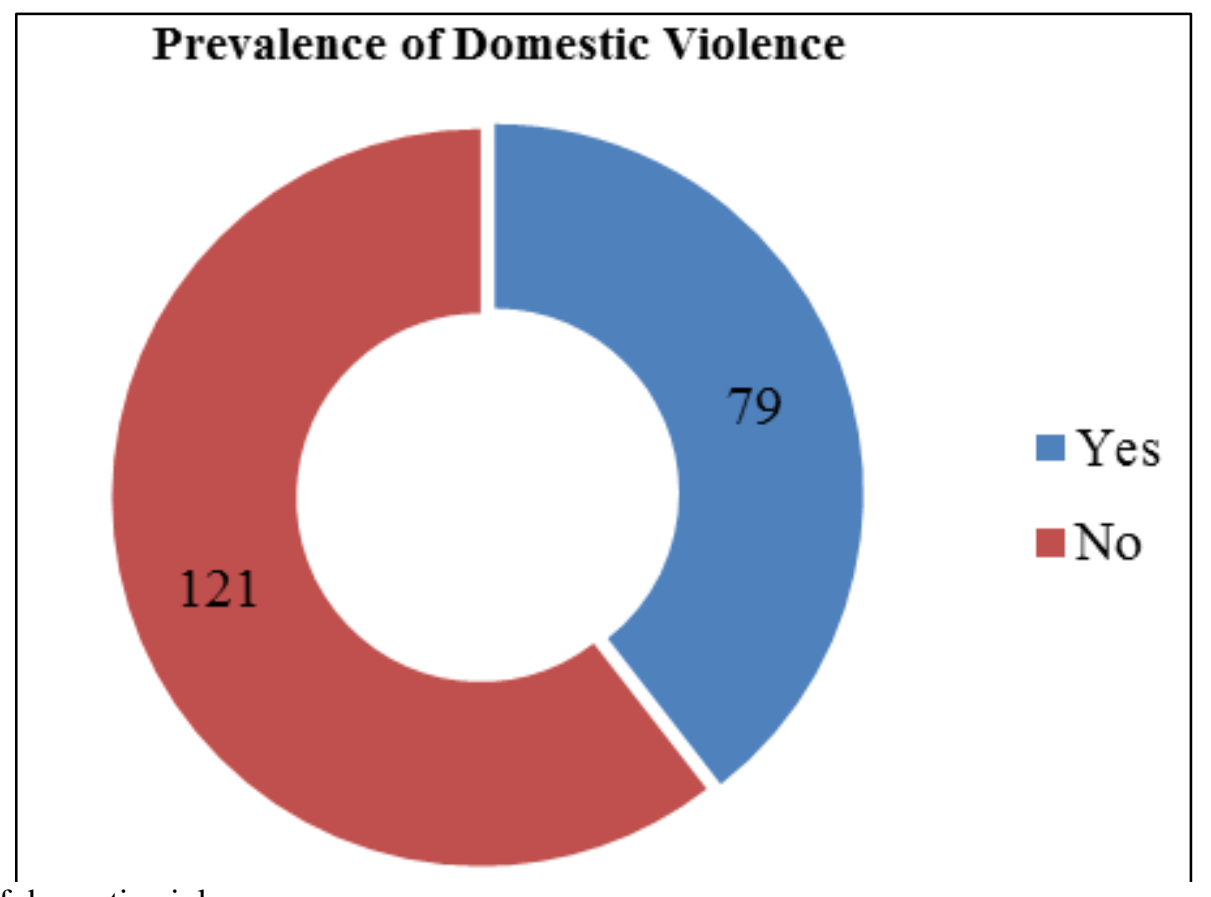

Fig 1: Prevalence of domestic violence 
Table 3: Distribution of study subjects based on prevalence of types of violence's

\begin{tabular}{|l|l|c|c|}
\hline Type of Violence (N=79) & & $\mathbf{N}$ & \% \\
\hline \multirow{4}{*}{$\begin{array}{l}\text { Physical Violence* } \\
(\mathrm{n}=35)\end{array}$} & Beating and Slapping & 30 & 85.7 \\
\cline { 2 - 4 } & Throwing things on her & 6 & 17.1 \\
\cline { 2 - 4 } & Twisting arm & 7 & 20.0 \\
\cline { 2 - 4 } & Pulling hair & 6 & 17.1 \\
\cline { 2 - 4 } & Kicking & 7 & 20.0 \\
\cline { 2 - 4 } & Pushing & 8 & 22.8 \\
\cline { 2 - 4 } & Attacking her with weapons & 3 & 8.5 \\
\cline { 2 - 4 } & Burning & 3 & 8.5 \\
\cline { 2 - 4 } & Other reasons which are not cited here & 3 & 8.5 \\
\hline \multirow{4}{*}{$\begin{array}{l}\text { Psychological violence* } \\
\text { (n=59) }\end{array}$} & Insult & 50 & 84.7 \\
\cline { 2 - 4 } & Humiliating in front of others & 40 & 67.7 \\
\cline { 2 - 4 } & Intimidation & 9 & 15.3 \\
\cline { 2 - 4 } & Belittling & 23 & 38.9 \\
\hline \multirow{3}{*}{$\begin{array}{l}\text { Sexual Violence* } \\
\text { (n=15) }\end{array}$} & Pressure for sex & 12 & 80.0 \\
\cline { 2 - 4 } & Forceful unprotected sex & 3 & 53.3 \\
\cline { 2 - 4 } & Hurt for sex & 3 & 20.0 \\
\hline
\end{tabular}

*Multiple Responses

In the present study, 79 (39.5\%) women had experienced some type of domestic violence in the past 1 year. (Fig 1). Among them, 59(74.7\%) of them reported psychological violence, 35(44.3\%) had physical violence and the sexual violence 15(18.9\%) was cited less frequently. Among 64(81.0\%) of women suffered from any one type of violence, $14(17.7 \%)$ of women suffered from any two types of violence and 10(12.7\%) suffered from three types of violence.

Among psychological violence, Insult (84.7\%), humiliating in front of others (67.7\%) and belittling (38.9\%) were found as common. In the physical violence, beating and slapping (85.7\%) were the most common types found. Among Sexual Violence, Pressure for sex 12(80\%) was the most common type reported.

Table 4: Distribution of study subjects based on frequency of violence in the last one year

\begin{tabular}{|l|c|c|}
\hline Frequency of violence in the last one year & Frequency $(\mathbf{N}=\mathbf{7 9})$ & Percentage \\
\hline Everyday & 3 & 3.8 \\
\hline Few times in a week & 15 & 19.0 \\
\hline Few times in a month & 42 & 53.2 \\
\hline Few times in a year. & 19 & 24.0 \\
\hline
\end{tabular}

Table 5: Distribution of study subjects based on domestic violence experienced from

\begin{tabular}{|l|l|l|}
\hline \multicolumn{1}{|c|}{ Domestic Violence experienced from } & Frequency (N= 79) & Percentage \\
\hline Husband & 48 & 60.8 \\
\hline Other family members of husband (In-Law) & 31 & 39.2 \\
\hline
\end{tabular}

*Multiple Responses

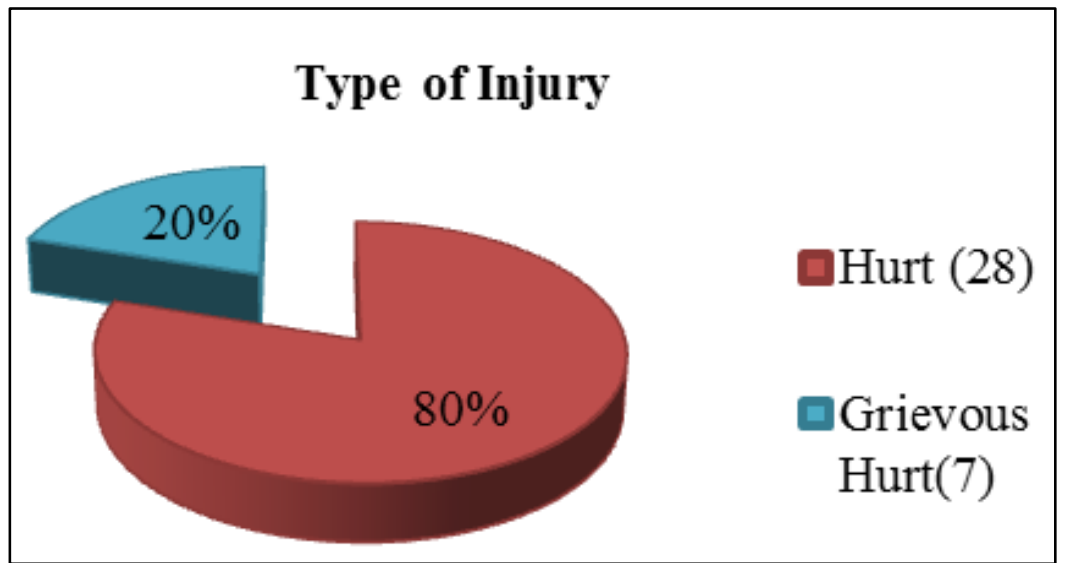

Fig 2: Pie chart showing distribution of study subjects based on type of injury sustained in physical violence 
In the present study, (Table 4) 42(53.2\%) of the victims suffered domestic violence, few times in a month, the perpetrators were mostly husbands $48(60.8 \%)$ followed by other members in family like mother-in-law, father-in-law 31(39.2 \%).(Table 5) Among the victims suffered from physical violence (35), 28(80.0\%) reported simple hurt and 7(20.0\%) suffered from Grievous hurt (as per legal definition of Indian IPC code 320).(Fig. 2).

The most common reason cited for domestic violence was alcohol use by husband (77.2\%), financial distress (40.5\%), followed by conflict over cooking (36.7\%). The other includes, $19 \%$ reported due to arguing and conflict with in-laws, $15.2 \%$ due to children related issues, $11.4 \%$ were due to dowry and not having male child. The least reason found to be external marital affairs (6.3\%) and refusal to have sex (3.8\%). (Fig. 3)

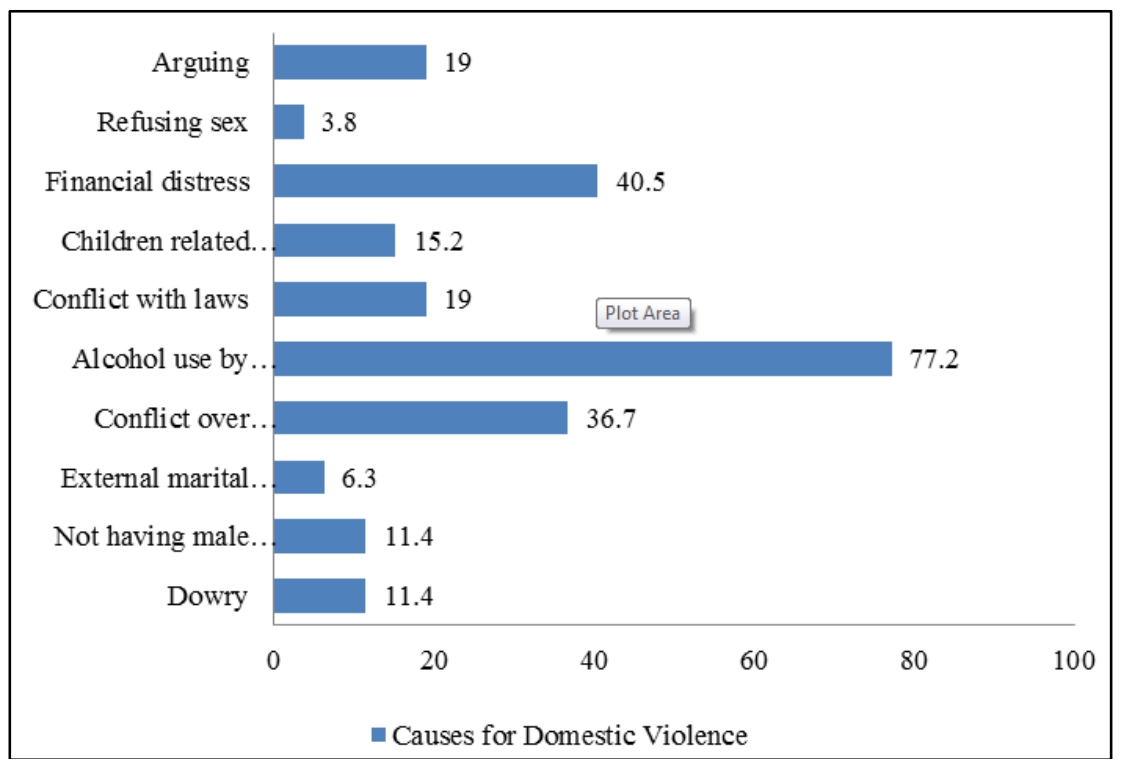

*Multiple Responses

Fig. 3: Distribution of study subjects based on causes for Domestic Violence $(\mathrm{N}=79)$

Table 6: Distribution of study subjects in relation toreasons for stay in violent relationship

\begin{tabular}{|l|c|c|}
\hline \multicolumn{1}{|c|}{ Reasons to stay in violent relationship } & Frequency $(\mathbf{N}=\mathbf{7 9})$ & Percentage \\
\hline Stayed for children & 55 & 69.6 \\
\hline Social stigma & 30 & 37.9 \\
\hline Acceptance & 24 & 30.4 \\
\hline Love for husband & 38 & 48.1 \\
\hline Financial dependence & 1 & 1.3 \\
\hline
\end{tabular}

*Multiple Responses

Table 7: Distribution of study subjects based on victim's response to violence

\begin{tabular}{|l|c|c|}
\hline \multicolumn{1}{|c|}{ Response to violence } & Frequency $(\mathbf{N = 7 9 )}$ & Percentage \\
\hline Parents \& Relatives support & 31 & 39.2 \\
\hline Friends \& Neighbour's support & 14 & 17.7 \\
\hline Tolerate it & 57 & 72.2 \\
\hline Try to convince & 23 & 29.1 \\
\hline Left the house & 6 & 7.6 \\
\hline Support groups ${ }^{+}$ & 3 & 3.8 \\
\hline Attempted suicide & 0 & 0.0 \\
\hline
\end{tabular}

${ }^{+}$Support groups include Mahila Mandals, NGOs etc.

*Multiple Responses

The most common reason given by victim to stay in violent relationship includes (Table 6), stayed for children 55 (69.6\%), love for husband 38(48.1\%), social stigma 30(37.9\%) and acceptance 24(30.4\%). The common victim's response to violence (Tables 7) includes tolerating 57(72.2\%), seeking for parents \& relative's support 31(39.2\%), try to convince $23(29.1 \%)$ and friends \& neighbour's support 14 (17.7\%). The least was found to be approaching support groups like Mahila Mandals, NGOs etc. and no cases were found to have been attempted suicide. 
Table 8: Results of logistic regression done on the study variables $(\mathrm{N}=200)$

\begin{tabular}{|c|c|c|c|c|c|}
\hline \multirow[b]{2}{*}{ Characteristics } & \multirow[b]{2}{*}{ B } & \multirow[b]{2}{*}{$\operatorname{Exp}(B)$} & \multicolumn{2}{|c|}{$95 \%$ C.I for $\operatorname{Exp}(B)$} & \multirow{2}{*}{$\begin{array}{c}\mathbf{P} \\
\text { value }\end{array}$} \\
\hline & & & Lower & Upper & \\
\hline \multicolumn{6}{|l|}{ Age groups } \\
\hline Age $>37$ years & 1.563 & 4.774 & .818 & 27.845 & .082 \\
\hline Age $18-27$ years & -1.386 & .250 & .042 & 1.490 & .128 \\
\hline Age 28-37 years & 0 & & & & \\
\hline \multicolumn{6}{|l|}{ Women's Education } \\
\hline Graduate & -19.089 & 5.123 & 0.060 & 1.256 & .994 \\
\hline Illiterate & -2.265 & .104 & .004 & 2.468 & .161 \\
\hline Primary & -1.654 & .191 & .020 & 1.812 & .149 \\
\hline PUC & -.657 & .519 & .080 & 3.345 & .490 \\
\hline Secondary & 0 & & & & \\
\hline \multicolumn{6}{|l|}{ Occupation of woman } \\
\hline Agriculture & -35.436 & 4.076 & 2.422 & 6.859 & .000 \\
\hline Business & -35.453 & 4.007 & 4.761 & 3.373 & .000 \\
\hline Government service & -32.229 & 1.007 & 4.302 & 2.359 & .000 \\
\hline Housewife & -47.850 & 1.656 & 0.686 & 4.214 & .985 \\
\hline Labour & -32.490 & 7.759 & 7.759 & 7.759 & \\
\hline Private sector & -21.087 & 6.950 & 0.798 & 3.912 & .997 \\
\hline Professional & 0 & & & & \\
\hline \multicolumn{6}{|l|}{ Husband's education } \\
\hline Graduate & 4.040 & 56.842 & 5.865 & 550.909 & .000 \\
\hline Illiterate & 1.348 & 3.852 & .126 & 118.000 & .440 \\
\hline Post graduate & 18.203 & 8.025 & 0.658 & 5.899 & .998 \\
\hline Primary & 1.716 & 5.562 & 1.008 & 30.697 & .049 \\
\hline PUC & -1.652 & .192 & .017 & 2.216 & .186 \\
\hline Secondary & 0 & & & & \\
\hline \multicolumn{6}{|l|}{ Smoking } \\
\hline Yes & -3.410 & .033 & .006 & .169 & .000 \\
\hline No & 0 & & & & \\
\hline \multicolumn{6}{|l|}{ Alcohol } \\
\hline Yes & -4.109 & .016 & .003 & .102 & .000 \\
\hline No & 0 & & & & \\
\hline
\end{tabular}

$\mathrm{B}=$ slope of the gradient in logarithmic scale, $\operatorname{Exp}(\mathrm{B})=$ antilog of $\mathrm{B}=$ Adjusted Odds ratio

In order to assess overall effect of various variables on Domestic violence, the Multiple Logistic Regression model was applied (Table 8). The variables that were statistically significant in the univariate logistic regression analysis were included in the multiple logistic regression model. A statistically significant association was observed between woman's occupation status such as agriculture, business \& government service, husband's educational status such as graduation \& primary school education and alcohol \& smoking habits of them with domestic violence may be considered as independent risk factors for developing domestic violence.

In relation to awareness of victim about the presence of legal provisions against domestic violence were 60(75.9\%). However, the behaviour to seek legal support was very less $7(8.9 \%)$ and most common reason gave was social stigma $22(27.8 \%)$ attached to the society.

Interestingly we found, 34(43.04\%) of male partners knew about domestic violence experienced by their mother during their childhood, $25(31.7 \%)$ of children witness domestic violence in the family and $29(36.7 \%$ ) of victims had health issues due to domestic violence, among which anxiety and depression was the most common issue observed.

\section{Discussion}

Violence against female occurs even before her life starts and continues throughout her whole life. Domestic violence against women is a global problem and present in every country cutting across the boundaries of culture, class, education, income, ethnicity and age. ${ }^{4}$ It estimated that about $20 \%-50 \%$ of women in most countries have experienced domestic violence from an intimate partner. This is also a vicious cycle that will beget future involves in violence, as it becomes a norm for the children growing up in this setting.

In the present study, the current prevalence of domestic violence against married women of reproductive age in rural Mandyawas $39.5 \%$. In a similar study by Vachhani et al., reported slightly higher prevalence $58 \%$ in rural population 
of Surendranagar district of Gujarat. ${ }^{5}$ In various studies conducted among women in rural area of Puducherry, South India $^{6}$, and Eastern India ${ }^{7}$ reported, similar type prevalence $56.7 \%$ and $56 \%$ respectively. According to a study by Sarkar M; reported much lesser incidence rate $23.4 \%$, among adult and adolescent females in Dearah village of Singur, West Bengal. ${ }^{8}$ According to studies conducted in Niladri Vihar, Bhubaneswar, and in the slum of Alamgunje, Burdwan district of West Bengal, the prevalence of domestic violence was $35 \%$ and $40.4 \%$ respectively. This is in accordance with our study. However, these studies were conducted in urban slums. ${ }^{9}$

In relation to type of violence, $59(74.7 \%)$ reported of psychological violence, $35(44.3 \%)$ of them about physical violence and $15(18.9 \%)$ about sexual violence. In a similar study, Verbal/psychological violence was the most common form of domestic violence $(85.7 \%)$ followed by physical $(71.4 \%)$ and sexual violence $(57.1 \%) .{ }^{9}$ In the study on eastern India also reported, 52\% prevalence of psychological violence, $16 \%$ physical and $25 \%$ in the sexual violence. ${ }^{7}$ A study conducted in a rural area of Puducherry reported 51.3\% psychological violence, $40 \%$ physical violence, and $13.5 \%$ sexual violence. ${ }^{6}$ A study on urban slum population in the Bhubaneswar reported, $34 \%$ suffered from physical, $35 \%$ emotional and $17 \%$ from sexual violence. $^{10}$ However, a study from urban part of Aurangabad, Maharashtra reported that, $57.71 \%$ experienced physical and $50 \%$ psychological violence. ${ }^{11}$

In the psychological violence, insult 50 (84.7\%), humiliating in front of others $40(67.7 \%)$ and belittling $23(38.9 \%)$ were found to be the most common. In relation to physical violence, beating \& slapping $30(85.7 \%)$ was the most common followed by pushing $8(22.8 \%)$ and pressure for sex $12(80 \%)$ was the most common form observed among sexual violence. In a study by Bhattacharya A, humiliation $82(91.1 \%)$ was the commonest form of psychological violence $(\mathrm{n}=90)$. Slapping and or beating $67(89.3 \%)$, kicking 54(72\%), were the major forms of physical violence $(\mathrm{n}=75)$ and most common form of sexual violence $(\mathrm{n}=60)$ was forced sexual intercourse $35(58.3 \%) .{ }^{9}$ The study conducted by Mohapatra I eta al, also reported humiliating in front of others $18(51.4 \%)$ and insult $9(25.7 \%)$ were the most common forms of emotional violence. Hitting \& beating $15(42.8 \%)$ and slapping $14(40.0 \%)$ were the commonest forms of physical violence. In relation to sexual violence, physical force to have sexual intercourse was the commonest. ${ }^{10}$ In a study by Nair et al. in rural area of Gujarat showed that, slapping (80\%), kicking, punching or hitting with an object $(74 \%)$, pulling by the hair/dragging (27\%) and forced sex (27\%) were the types of reported physical abuse. ${ }^{12}$

With respect to frequency of violence in the past one year, females reported that, maximum $42(53.2 \%)$ of them suffered violence few times in a month, followed by few times in a year 19(24.0\%) and then few times in a week 15 (19\%) in the present study. Sarkar M observed that, maximum number of females $(81.82 \%)$ exposed to domestic violence few times in the year. Others reported the frequency of violence as few times in a week and few times in a month $(9.09 \%$ each $){ }^{8}$ The frequency of domestic violence as reported by Bhattacharya A, every day (20.95\%), weekly $(19.05 \%)$, once in 15 days $(22.86 \%)$, monthly $(24.76 \%)$ and occasionally $(12.38 \%) .{ }^{9}$

In the study, husband $48(60.8 \%)$ was responsible for violence among majority of the women. Some women reported that in-laws (husbands' parents) 31 (39.2\%) were responsible for few acts of violence, which is similar to many other studies. Mohapatra I in their study reported that, husband $(18 \%)$ was mostly responsible for violence among majority of women, followed by in-laws particularly emotional violence and few cases of physical violence wherein in-laws and husbands' kin's $(7 \%)$ were involved. ${ }^{10}$ In a study by Sarkar $M$ on rural area of west Bengal reported the most common perpetrator of domestic violence is by husband $24(72.73 \%$.) and slapping as the specific act of physical assault $72.73 \%) .{ }^{8}$ However, Nair U reported that, even though the victims were mostly wives $(78 \%)$ and the perpetrators were their husbands, frequent physical violence was much less reported than verbal and psychological harassments. ${ }^{12}$

Among the victims suffered physical violence (35), $28(80.0 \%)$ reported of simple hurt which includes minor injuries without treatment, minor pain, sprain, bruises and small cuts. 7(20.0\%) suffered from Grievous hurt (as per legal definition of Indian IPC code 320) which required medical attention. In a study by Shreemanta, on rural population of Andhra Pradesh also reported of similar pattern, where $70 \%$ of them sustained injuries of a nature which required no medical attention or house hold remedy and $30 \%$ of them received injuries which required hospital treatment. ${ }^{13}$ Other study reported, $44.5 \%$ of them who had injuries had pain lasted for more than a day, followed by $31.5 \%$ of them having minor injuries. Medical attention/hospitalization was required by $17 \%$ of the individuals. $^{14}$

The most common reason cited for domestic violence was alcohol use by husband $(77.2 \%)$, financial distress $(40.5 \%)$, followed by conflict over cooking $(36.7 \%)$. The other includes, $19 \%$ reported due to arguing and conflict with in-laws, $15.2 \%$ due to children related issues, $11.4 \%$ were due to dowry and not having male child. Sina A found that the main factors behind domesticviolence were alcohol addiction of the husband, followed by 'not cooking properly' and dowry related problem. ${ }^{15}$ In the study by Kocacik and Dogan, economic problems were reported as the most important reason for domestic violence $(31.4 \%) .{ }^{16}$ Mohapatra I in their study reported, alcohol addiction of the husband (20\%), dowry related problems and not having a male child (4\%), as well as some inconspicuous reasons like not cooking properly or talking with neighbours $(6 \%)$ as the major factors associated with domestic violence. ${ }^{10}$

The most common reason gave by victim to stay in violent relationship includes, stayed for children 55 $(69.6 \%)$, love for husband $38(48.1 \%)$, social stigma $30(37.9 \%)$ and acceptance $24(30.4 \%)$. The common victim's response to violence includes tolerating 57(72.2\%), 
seeking for parents \& relative's support $31(39.2 \%)$, try to convince $23(29.1 \%)$ and friends \& neighbour's support $14(17.7 \%)$. The least was found to be approaching support groups like Mahila Mandals, NGOs etc. and no cases were found to have been attempted suicide.

By multiple logistic regressions, the overall effects of various socio-demographic variables were assessed. It was found that, the occupational status of the women, such as agriculture, business \& government service i.e, selfdependency were protective against domestic violence. However, the husband's educational status such as graduation \& primary school education were found to be strongly associated with domestic violence. In relation to habits of their husband such as use of alcohol and smoking were independent risk factors for developing domestic violence.

Awareness about, the presence of legal provisions against domestic violence was found in 60(75.9\%). However, the behaviour to seek legal support was only $7(8.9 \%)$ and most common reason reported was social stigma $22(27.8 \%)$ attached to our Indian society.

Bhattacharya et al., reported, majority of the victimized women preferred to be silent sufferers. These women had never sought any help, even from their relatives and close friends. They preferred to rely upon their own strategies to deal with the situations. The help seeking behaviour was found only in one third $(31.5 \%)$ of women who had faced violence in their lifetime. Among them, 21.9\% women sought help from their parents, followed by $16.2 \%$ from friends/neighbours and only $6.7 \%$ had reported to police which represented the tip of the iceberg. ${ }^{9}$ Shrivastava PS reported $2(2 \%)$ women had reported to police and only 4 (4\%) sought help from NGOs, even in urban population. ${ }^{17}$ The similar results have been reported in other studies where $32.7 \%$ and $74.4 \%$ respectively did not report the abusive situations in which they were living and those who sought help, most often from their own families. ${ }^{18,19}$ Another similar study revealed that $74.9 \%$ never sought for any help; $13.9 \%$ sought for first aid, $4.9 \%$ sought for professional help, $3.6 \%$ reported to police. ${ }^{20}$ A study by Rajini S reported that, $26 \%$ of the respondents have never sought any type of help from anyone, $35 \%$ have sought help from some source and 39\% have said someone about the violence they experienced. ${ }^{14}$ Similarly, in another study $73 \%$ of them have never sought any help and only $23 \%$ of the women have sought some help. ${ }^{21}$

From the above findings, we can conclude that inspite of relatively long history of public and private activism against the domestic violence it is still continued to be a part of culture. In India, especially the men believe, violence against women as a means of discipline. Inspite of their rude and aggressive behaviour, most women neither protest nor retaliate against abuses for reasons of shame, fear, guilt, or simply because they do not want to be disloyal to their partners. Lack of education and economic dependency most often make them less confident to disclose their problems freely without any hesitation.

\section{Limitations}

1. The results of the study cannot be generalised since it is a cross-sectional study.

2. Recall bias and conscious falsification due to social stigma attached to it or any another reason cannot beruled out at cross-sectional study.

\section{Conclusion}

Overall prevalence of domestic violence was found to be $39.5 \%$. Psychological violence $59(74.7 \%$ ) was the most common type of domestic violence. The occupational status of the women, such as agriculture, business \& government service, the husband's educational status including graduation \& primary school education, and alcohol \& smoking habits of them were independent risk factors for developing domestic violence.

In this context, improving the education status and employment of the women, increasing the community awareness regarding risk factors for domestic violence\& encouraging supportive groups to deal with domestic violence, stringent rules on sale of alcohol and bringing strict regulations \& amendments to the existing law against domestic violence are recommended to curb the incidence rate of violence against women.

\section{Acknowledgments}

The authors thank the study subjects who are involved in the study, department of Community Medicine and Interns of Adichunchanagiri Institute of Medical Sciences, B G Nagara.

\section{Source of Funding}

None.

\section{Conflict of Interest}

None.

\section{Ethical Approval}

An Institutional Ethical Committee clearance was obtained before study.

\section{References}

1. Violence against women: A priority health issue.WHO/FRH/WHD/97.8. Geneva: World Health Organization; 1997. World Health Organization.

2. Kapoor S. Domestic violence against women and girls. Innocenti Digest no. 6. UNICEF Innocenti Research Centre: Florence. Arti Grafiche Ticci, Siena - Italy;2000 Jun. 30p.

3. Ministry of Health and Family Welfare, Government of India. Fact Sheet: National Family Health Survey (NFHS-4) 2015-16. Available at: http://rchiips.org/nfhs/nfhs4.shtml.[Accessed on 2019 Apr 4]

4. Burge SK. Partner violence. In: Rosenfeld JA, Acheson LS, Admire JB eds. Women's health in primary care.

Pennsylvania, USA, Williams \& Wilkins, 1997: 241-255.

5. Vachhani PV, Bhimani NR, Purani SK, Kartha GP. Epidemiology of domestic violence among married women: a community based cross-sectional study. Int J Community Med Public Health 2017;4(4):1353-59.

6. George J, Nair D, Premkumar NR, Saravanan N, Chinnakali P, Roy $\mathrm{G}$ et al. The prevalence of domestic violence and its 
associated factors among married women in a rural area of Puducherry, South India. J Family Med Prim Care 2016;5(3):672-6.

7. Babu BV, Kar SK. Domestic violence against women in eastern India: a population-based study on prevalence and related issues. BMC Public Health 2009;9(1):1-15.

8. Sarkar, M. (2010). A study on domestic violence against adult and adolescent females in a rural area of West Bengal. Indian $J$ Community Med 2010;35(2):311.

9. Bhattacharya A, Basu M, Das P, Sarkar AP. Domestic violence: A hidden and deeply rooted health issue in India. South East Asia J Public Health 2013;3(1):17-23.

10. Mohapatra I, Mistry C. Domestic Violence among Ever Married Women of Reproductive Age Group in a Slum Area of Bhubaneswar. J Med Sci Clin Res 2017;05(3):19593-98.

11. Khadilkar HA, Paunikar AP, Doibale MK, Kuril BM, Gaikwad $\mathrm{AV}$, Andurkar SP, et al. Study of domestic violence against married women in the field practice area of urban health training centre, Aurangabad, Maharashtra. Int J Community Med Public Health 2018;5:702-7.

12. Nair U, Sadhwani H, Uttekar V. CRDC Research Summary. Baroda: Centre for Research in Development and Change; 2000. A study on domestic violence in rural Gujarat.

13. Kumar Dash S. Violence against women; Evidence from rural Andra Pradesh. (Eluru, W.G.Dist), India. Indian Academy Forensic Med 2006:28(4); 0971-0973.

14. Rajini S, Kamesh vell C, Senthil S. Prevalence of domestic violence and health seeking behaviour among women in rural community of Puducherry - A cross sectional study. Int J Cur Res Rev 2014;6(16):20-23.
15. Sinha A, Mallik S, Sanyal D, Dasgupta S, Pal D, Mukherjee et al. A Domestic violence among ever married women of reproductive age group in a slum area of Kolkata. Indian $J$ Public Health 2012;56(1):31-6.

16. Kocacik F, Dogan O. Domestic violence against women in Sivas, Turkey: Survey study. Croat Med J 2006;47:742-9.

17. Shrivastava PS, Shrivastava SR. A study of spousal domestic violence in an urban slum of mumbai. Int J Prev Med 2013;4(1):27-32.

18. Kamat U, Ferreira AMA, Motghare DD, Kamat N, Pinto NR A cross-sectional study of physical spousal violence against women in Goa. Health Line 2010;1:34-40.

19. Sharma KK, Vasta M. Domestic violence against nurses by their marital partners: A facility-based study at a tertiary care hospital. Indian J Community Med 2011;36: 222-7.

20. Ray K, Chakraborty M, Roy H, Gupta S, Banerjee I. 'Violence against Women': Evidence from a Cross Sectional Study in Urban Area of North Bengal. Al Ameen J Med Sci 2012;5:15764.

21. V.R.S. Kavitha. Spousal Domestic Violence of Married women in India. J Sociology Soc Anth 2012;3(1):7-13.

How to cite this article: Vinay J, Raghavendra SK, Thejaswini P, Kumar AGV. A cross-sectional study on domestic violence among married women of reproductive age in rural mandya. Indian $J$ Forensic Community Med 2019;6(3):188-196. 